\title{
Chemical composition and antioxidant activity of some apricot varieties at different ripening stages
}

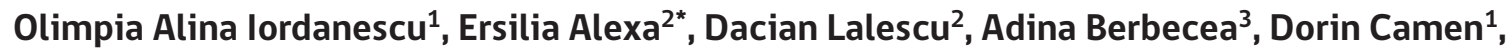 \\ Mariana Atena Poiana², Diana Moigradean², and Maria Bala ${ }^{1}$
}

${ }^{1}$ Banat's University of Agricultural Sciences and Veterinary Medicine "King Michael I of Romania" from Timisoara, Faculty of Horticulture and Forestry, Calea Aradului 119, Timisoara 300645, Romania.

${ }^{2}$ Banat's University of Agricultural Sciences and Veterinary Medicine "King Michael I of Romania" from Timisoara, Faculty of Food Processing Technology, Calea Aradului 119, Timisoara 300645, Romania. *Corresponding author (alexa.ersilia@yahoo.ro).

${ }^{3}$ Banat's University of Agricultural Sciences and Veterinary Medicine "King Michael I of Romania" from Timisoara, Faculty of Agriculture, Calea Aradului 119, Timisoara 300645, Romania.

Received: 24 January 2018; Accepted: 1 May 2018; doi:10.4067/S0718-58392018000200266

\begin{abstract}
Apricot (Prunus armeniaca L.) is a fruit tree species widespread in Europe due to the high nutritional value of its fruit. In this study, the changes in the chemical composition of seven apricot cultivars were studied during three fruit ripening stages. Proximate composition (water content, ash, lipids, proteins, carbohydrates) was determined by official AOAC methods, macro- and microelements (potassium $(\mathrm{K})$, calcium $(\mathrm{Ca})$, magnesium $(\mathrm{Mg})$, and iron $(\mathrm{Fe})$ ) were detected by atomic absorption spectroscopy (AAS), while antioxidant capacity and total phenolic compounds were determined by spectrophotometric methods. Vitamin C content was determined by titration using 2,6-dichlorophenol indophenol dye. The present research highlighted the variation between chemical composition as related to variety and stage of maturity. Protein and moisture of apricot fruit decreased during the different ripening stages in all cultivars, while lipids, carbohydrates, and ash content increased during ripening. The water content ranged from $79.87 \%$ to $88.6 \%$, protein between $0.66 \%$ and $1.3 \%$, and lipids between $0.1 \%$ and $0.57 \%$. Generally, the highest macro-element content was detected in the first ripening stage. The total phenolic content dynamics displays a significant increase during ripening. The highest value of ferric reducing antioxidant power (FRAP) activity $\left(0.357 \mu \mathrm{M} \mathrm{Fe}^{2+} \mathrm{g}^{-1} \mathrm{FW}\right)$ was obtained for 'Sirena' at the halfripe stage, while the lowest value was detected for the same cultivar at the unripe stage $\left(0.045 \mu \mathrm{M} \mathrm{Fe}^{2+} \mathrm{g}^{-1}\right)$. In conclusion, the study of the chemical composition in different development stages represents a useful tool in horticulture to optimize the management of the nutritional potential of apricot fruit.
\end{abstract}

Key words: Antioxidant activity, apricot, elements, polyphenols, proximate composition, Prunus armeniaca.

\section{INTRODUCTION}

Apricot (Prunus armeniaca L.) is one of the fruit tree species planted on a large scale in Southeast Europe. The high food value of apricots and apricot-based products have led scientific research specialists to diversify this variety by creating or adding new apricot varieties that behave well under European climatic conditions.

Apricots have important nutritional properties; it is strongly recommended to consume them in cases of vitamin A and trace element deficiencies, anemia, physical and mental fatigue, depression, neurosis, stress, etc. (Iordanescu and Micu, 2012). Apricots are a tonic for the nervous system and increase the body's natural defense reaction. Since they have an alkaline action, apricots help maintain the acid-base balance in the blood and body tissues and decrease acidity resulting 
from a diet too rich in meat and flour products. Apricot fruit contain the major minerals $\mathrm{K}, \mathrm{Ca}$, and $\mathrm{Mg}$ (Drogoudi et al., 2008). Apricot fruit contains lycopene, which helps to prevent cancer and protects the body from high cholesterol, thus preventing heart disease.

Some apricot cultivars have recently been evaluated for their antioxidant profile, suggesting their health-promoting effects in the human diet (Leccese et al., 2010). Antioxidant compounds, such as carotenoids, polyphenols, and vitamin C, have been reported in high amounts in apricot fruit (Drogoudi et al., 2008; Dragovic-Uzelac et al., 2009; Hegedüs et al., 2011; Sochor et al., 2011; Caliskan et al., 2012; Fan et al., 2018; Fratianni et al., 2018).

Previous studies have indicated that the chemical composition of apricot fruit depends on the cultivars (Gatti et al., 2009; Hussain et al., 2010; Mratinic et al., 2011; Iordanescu et al., 2012), geographic area (Gatti et al., 2009; Milosevic et al., 2010; Campbell et al., 2011), cultivation system (Leccese et al., 2010), ripening process (Hegedüs et al., 2011; Ayour et al., 2017), and conservation or processing technology (Hussain et al., 2013). The dynamics of the chemical composition and antioxidant capacity observed in different phenophases shows that the maturity stage of apricot fruit can be appreciated according to these proprieties (Hegedüs et al., 2011; Ayour et al., 2017).

The present study was undertaken to evaluate the nutritional significance of seven apricot varieties from Romania at different ripening stages based on their proximate composition (moisture, ash, proteins, lipids, total carbohydrates), macro- and microelements ( $\mathrm{K}, \mathrm{Ca}, \mathrm{Mg}$, and $\mathrm{Fe}$ ), vitamin $\mathrm{C}$ content, total phenolic content (TP), and antioxidant capacity (AC); apricot cultivars were also sorted in accordance with their chemical content due to their important nutritional characteristics.

\section{MATERIALS AND METHODS}

\section{Plant material}

Apricot fruit of seven apricot varieties maintained in a collection orchard of the Didactic Station Timisoara $\left(45^{\circ} 45^{\prime} \mathrm{N}\right.$; $21^{\circ} 13^{\prime}$ E) at the Banat University of Agricultural Sciences and Veterinary Medicine, Timisoara, Romania, were harvested at three ripening stages. The studied fruit belong to the 2012 harvest. The seven studied apricot tree varieties cultivated in Romania were Hungarian Best (obtained at the Fruit Science Station Cluj Napoca), Selena, Sirena, Olimp, Sulmona, Sulina, and Silvana (obtained at SCDP Constanța).

Fruit were harvested at three ripening stages: I) unripe (UR; undeveloped green fruit), II) half-ripe (HR; normal-sized and slightly yellowing fruit), and III) fully ripe (FR; normal-sized, yellowing fruit with red blush).

Ten fruit were collected from each variety. Fruit were frozen until analysis. The stones of the apricots had been removed before cutting and blending. For analysis, apricots with skin were cut into small pieces and blended with a house blender. The homogenized sample was immediately used for analysis.

\section{Measurements}

Proximate composition was determined using official AOAC (1997) methods: Protein (method 954.01); fat (920.39); ash (923.03), and moisture (925.09). Total carbohydrate (TC) content was calculated as the difference. Results are reported in percentage (\%). To evaluate element contents, $3 \mathrm{~g}$ samples of blended apricots were burned at $550{ }^{\circ} \mathrm{C}$ in a furnace for $8 \mathrm{~h}$ (Nabertherm B150, Lilienthal, Germany). The ash was dissolved in $\mathrm{HCl} 20 \%$ and was brought to $20 \mathrm{~mL}$ in a volumetric flask. The selected minerals ( $\mathrm{K}, \mathrm{Ca}, \mathrm{Mg}$, and $\mathrm{Fe}$ ) were determined by atomic absorption spectroscopy (AAS; Varian 220 FAAS, Mulgrave, Victoria, Australia). Mix standard solutions (ICP Multi Element Standard solution IV CertiPUR) were purchased from Merck. Method detection limits (MDL mg L-1) for analyzed elements were $0.02 \mathrm{mg} \mathrm{L}^{-1}$ for $\mathrm{Mg}$ and $\mathrm{K}$, $0.06 \mathrm{mg} \mathrm{Fe} \mathrm{L}^{-1}$, and $0.03 \mathrm{mg} \mathrm{Ca} \mathrm{L}^{-1}$. Mean recoveries $\pm \mathrm{SD}(\%)$ for each element were $\mathrm{Fe}(92 \pm 3.421 \%), \mathrm{K}(99 \pm 0.543 \%)$, $\mathrm{Ca}(92 \pm 2.121 \%)$, and $\mathrm{Mg}(89 \pm 3.211 \%)$.

To evaluate total phenolic content (TP), antioxidant capacity (AC), and vitamin C, $5 \mathrm{~g}$ of blended sample were extracted twice with a $20 \mathrm{~mL}$ ethanol:water $(95: 5, \mathrm{v} / \mathrm{v})$ solution acidified with $\mathrm{HCl}(0.1 \%, \mathrm{v} / \mathrm{v})$ for $2 \mathrm{~min}$. The mixture was stirred at room temperature for 30 min with a shaker and mixer (Promax 1020, Heidolph Instruments, Schwabach, Germany); the mixture was stored at room temperature in the dark for $16 \mathrm{~h}$ and then filtered. Total phenols were analyzed by an adapted Folin-Ciocalteu colorimetric method described by Suarez et al. (2010). One milliliter of an appropriately diluted sample was mixed with $5 \mathrm{~mL}$ water and $1 \mathrm{~mL}$ Folin-Ciocalteu reagent and $3 \mathrm{~mL} 15 \%$ sodium carbonate and water was 
added to reach a final volume of $10 \mathrm{~mL}$. Samples were incubated at room temperature for $2 \mathrm{~h}$ in the dark before measuring absorbance at $750 \mathrm{~nm}$ with a UV-VIS spectrophotometer (Specord 205, Analytik Jena, Jena, Germany). The calibration curve was prepared using 0.05-0.5 $\mathrm{mM} \mathrm{L}^{-1}$ gallic acid equivalents (GAE). The results were expressed as $\mathrm{mg} \mathrm{GA} \mathrm{g}^{-1} \mathrm{FW}$.

Antioxidant capacity was detected by a ferric reducing antioxidant power (FRAP) assay. An aliquot (200 $\mu \mathrm{L})$ of the extract was added to $3 \mathrm{~mL}$ of FRAP reagent, and the reaction mixture was incubated in a water bath at $37^{\circ} \mathrm{C}$. The absorbance at $593 \mathrm{~nm}$ was measured after $30 \mathrm{~min}$ with a UV-VIS spectrophotometer (Specord 205, Analytik Jena, Jena, Germany). Antioxidant capacity was expressed as $\mu \mathrm{M} \mathrm{Fe}^{2+} \mathrm{g}^{-1} \mathrm{FW}$.

Vitamin $\mathrm{C}$ content was determined by titration using 2,6-dichlorophenol indophenol dye; $10 \mathrm{~mL}$ of extract (diluted 1:10) with $10 \mathrm{~mL}$ distilled water and $1 \mathrm{~mL} 1 \mathrm{~N} \mathrm{HCl}$ was titrated with 2,6-dichlorphenolindophenol natrium to obtain a pink color.

All chemicals and solvents used in this study were of analytical grade. The results were expressed on the basis of fresh weight $(\mathrm{FW})$. Each value was the mean of three $(\mathrm{n}=3)$ independent determinations.

\section{Statistical analysis}

Data were subject to one-way ANOVA and Duncan's Multiple Range Test (statistical significance at $\mathrm{P}<0.05$ ). Correlation analysis was performed. Principal component analysis (PCA) was applied to mean values of the measured traits, and Ward's clustering method was performed according to the squared Euclidean distance on 12 factors produced after PCA analysis. The PCA and cluster analysis (CA) were performed for 19 cases in which data from all measured traits were available. Statistical analyses were performed with Statistica 10.0 (StatSoft Inc., Tulsa, Oklahoma, USA).

\section{RESULTS AND DISCUSSION}

\section{Proximate composition}

Proximate composition (moisture, ash, fat, protein, and carbohydrate contents) are shown in Table 1. Our results highlighted a variation among values as related to variety and stage of maturity. The protein content varied between $0.66 \%$ and 1.3\%; the highest content was determined in 'Silvana' and the lowest in 'Sirena'. A decrease in apricot fruit protein during the different ripening stages was recorded for all varieties. The moisture content ranged from $79.87 \%$ to $88.6 \%$ and decreased during apricot fruit ripening stages.

Table 1. Effect of stage of maturity and variety on proximate composition in apricot fruit (mean values \pm SD).

\begin{tabular}{|c|c|c|c|c|c|}
\hline Variety and ripening stage & Moisture & Ash & Proteins & Lipids & Total carbohydrates \\
\hline & & & $-\%$ & & \\
\hline Sirena I & $83.60 \pm 0.40 \mathrm{gh}$ & $6.32 \pm 0.21 \mathrm{~h}$ & $1.33 \pm 0.01 \mathrm{a}$ & $0.283 \pm 0.060 \mathrm{j}$ & 7.42 \\
\hline Sirena II & $82.73 \pm 1.02 \mathrm{~h}$ & $4.16 \pm 0.58 \mathrm{~d}$ & $1.20 \pm 0.01 \mathrm{ab}$ & $0.326 \pm 0.065 \mathrm{a}$ & 11.58 \\
\hline Sirena III & $81.06 \pm 0.51 \mathrm{i}$ & $5.20 \pm 0.10 c$ & $0.89 \pm 0.02 b c$ & $0.387 \pm 0.061 \mathrm{a}$ & 12.46 \\
\hline Silvana I & $86.16 \pm 0.21 \mathrm{~d}$ & $1.65 \pm 0.13 \mathrm{i}$ & $1.12 \pm 0.07 \mathrm{ab}$ & $0.100 \pm 0.010 \mathrm{f}$ & 10.96 \\
\hline Silvana II & $82.43 \pm 0.40 \mathrm{~h}$ & $5.57 \pm 0.15 b$ & $0.69 \pm 0.50 \mathrm{c}$ & $0.137 \pm 0.025 c$ & 11.73 \\
\hline Silvana III & $79.87 \pm 0.35 \mathrm{j}$ & $6.23 \pm 0.06 \mathrm{a}$ & $0.66 \pm 0.01 \mathrm{c}$ & $0.140 \pm 0.043 c$ & 13.10 \\
\hline Hungarian Best I & $84.36 \pm 0.40 \mathrm{f}$ & $2.10 \pm 0.10 \mathrm{~h}$ & $1.06 \pm 0.07 b$ & $0.200 \pm 0.010 \mathrm{~d}$ & 12.34 \\
\hline Hungarian Best II & $83.03 \pm 0.06 \mathrm{~h}$ & $2.65 \pm 0.05 f$ & $0.76 \pm 0.01 \mathrm{c}$ & $0.256 \pm 0.040 \mathrm{e}$ & 13.30 \\
\hline Hungarian Best III & $81.47 \pm 0.42 \mathrm{i}$ & $5.52 \pm 0.28 b$ & $0.72 \pm 0.03 \mathrm{c}$ & $0.310 \pm 0.026 \mathrm{a}$ & 11.98 \\
\hline Olimp I & $88.07 \pm 0.11 \mathrm{ab}$ & $1.36 \pm 0.04 \mathrm{j}$ & $1.17 \pm 0.12 \mathrm{ab}$ & $0.383 \pm 0.047 \mathrm{a}$ & 9.18 \\
\hline Olimp II & $87.13 \pm 0.23 b c$ & $2.40 \pm 0.10 \mathrm{~g}$ & $0.93 \pm 0.05 b c$ & $0.470 \pm 0.026 \mathrm{f}$ & 9.07 \\
\hline Olimp III & $84.40 \pm 0.10 \mathrm{ef}$ & $2.70 \pm 0.10 f$ & $0.75 \pm 0.09 \mathrm{c}$ & $0.473 \pm 0.066 f$ & 11.68 \\
\hline Sulmona I & $86.20 \pm 0.10 \mathrm{~d}$ & $1.10 \pm 0.10 \mathrm{k}$ & $1.18 \pm 0.06 \mathrm{ab}$ & $0.306 \pm 0.047 \mathrm{~b}$ & 11.12 \\
\hline Sulmona II & $84.40 \pm 0.10 f$ & $1.80 \pm 0.10 \mathrm{i}$ & $0.87 \pm 0.02 b c$ & $0.323 \pm 0.021 \mathrm{a}$ & 12.41 \\
\hline Sulmona III & $83.70 \pm 0.27 \mathrm{~g}$ & $5.20 \pm 0.10 c$ & $0.81 \pm 0.01 \mathrm{c}$ & $0.283 \pm 0.040 \mathrm{j}$ & 10.01 \\
\hline Selena I & $88.60 \pm 0.20 a$ & $1.64 \pm 0.07 \mathrm{i}$ & $1.22 \pm 0.07 \mathrm{ab}$ & $0.140 \pm 0.036 c$ & 8.26 \\
\hline Selena II & $86.80 \pm 0.40 c$ & $1.80 \pm 0.10 \mathrm{i}$ & $0.96 \pm 0.06 b c$ & $0.183 \pm 0.015 \mathrm{~g}$ & 10.26 \\
\hline Selena III & $85.80 \pm 0.10 \mathrm{~d}$ & $2.80 \pm 0.08 \mathrm{ef}$ & $0.70 \pm 0.07 \mathrm{c}$ & $0.210 \pm 0.010 \mathrm{~d}$ & 10.49 \\
\hline Sulina I & $87.50 \pm 0.10 \mathrm{~b}$ & $3.00 \pm 0.2 \mathrm{e}$ & $1.27 \pm 0.05 \mathrm{ab}$ & $0.406 \pm 0.006 \mathrm{a}$ & 8.01 \\
\hline Sulina II & $86.00 \pm 0.20 \mathrm{~d}$ & $5.10 \pm 0.1 c$ & $1.05 \pm 0.06 b$ & $0.423 \pm 0.020 \mathrm{~h}$ & 7.28 \\
\hline Sulina III & $85.00 \pm 0.20 \mathrm{e}$ & $5.17 \pm 0.15 c$ & $0.82 \pm 0.05 c$ & $0.570 \pm 0.043 \mathrm{i}$ & 8.44 \\
\hline
\end{tabular}

Different letters in the same column indicate significant differences according to Duncan's test $(\mathrm{P} \leq 0.05)$. 
The statistical analysis showed that there were nonsignificant differences $(\mathrm{p}>0.5)$ between moisture content in the second ripening stage (HR) for 'Sirena', 'Silvana', and 'Hungarian Best' and in the UR stage for 'Olimp', 'Selena', and 'Sulina'.

The lipid content varied between $0.1 \%$ and $0.57 \%$ and increased during fruit development. The maximum value was recorded in 'Sulina' at the FR stage.

The ash and total carbohydrate concentrations were the lowest in immature fruit and the highest in ripe fruit. Fruit accumulate sugars and minerals during ripening to supply energy and nutrients (Hegedüs et al., 2011). The maximum ash content was recorded in 'Silvana' (6.23\%), while total carbohydrates recorded the highest value in the ripe fruit of 'Sirena'. Our results concurred with those reported by Hussain et al. (2010) for different apricot varieties.

\section{Selected element content}

The selected element ( $\mathrm{K}, \mathrm{Ca}, \mathrm{Mg}$, and $\mathrm{Fe}$ ) contents, expressed as $\mathrm{mg} 100 \mathrm{~g}^{-1} \mathrm{FW}$, are displayed in Table 2. Potassium, $\mathrm{Ca}$, and $\mathrm{Mg}$ are considered as major minerals of apricot fruit (Drogoudi et al., 2008). Magnesium is vital in chlorophyll metabolism and in the synthesis of carbohydrates, lipids, and proteins. The deficit of this element leads to lower carotenoid concentration (Negrea et al., 2012). The Mg content in our samples varied between 6.55 and $67.82 \mathrm{mg} 100 \mathrm{~g} \mathrm{~g}^{-1} \mathrm{FW}$. Results concurred with data reported for different apricot cultivars and hybrids cultivated in Europe (Drogoudi et al., 2008). Our results showed that the highest $\mathrm{Mg}$ content was detected in the first ripening stage $\left(67.82 \mathrm{mg} 100 \mathrm{~g} \mathrm{~g}^{-1} \mathrm{FW}\right)$ in 'Sulmona'. During the ripening process, a decrease in the content of some macronutrients, such as $\mathrm{K}$ and $\mathrm{Mg}$, was estimated (Pliszka et al., 2009; Rop et al., 2011). Regarding mineral composition, Akin et al. (2008) reported that the K level was significantly high and consistent concentrations of $\mathrm{Mg}, \mathrm{Zn}$, and Se were found in different apricot cultivars. The $\mathrm{Mg}$ content in the HR stage was between 7.44 and $18.67 \mathrm{mg} 100 \mathrm{~g} \mathrm{~g}^{-1} \mathrm{FW}$ and between 6.55 and $19.59 \mathrm{mg} 100 \mathrm{~g}^{-1} \mathrm{FW}$ in the FR stage. The maximum value in the RP stage was recorded for 'Olimp'.

The $\mathrm{K}$ content recorded the same profile as $\mathrm{Mg}$ during ripening. The $\mathrm{K}$ content was the maximum content in the first

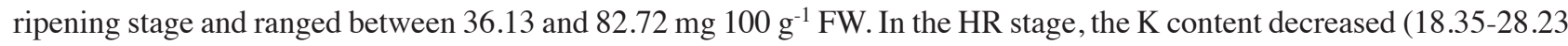

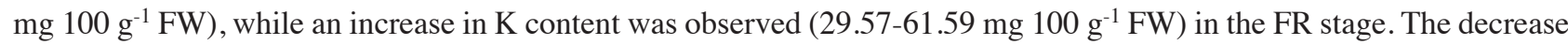
in the content of macro-elements, including $\mathrm{K}$, during ripening was also reported in other fruits (Rop et al., 2011). The highest $\mathrm{K}$ content in the ripening stage was detected in 'Selena', followed by 'Sirena' and 'Best Hungarian'. Previous studies reported a supply of $\mathrm{K}$ in different apricot varieties that were higher than the values recorded in the present study (1410-2087 mg K $100 \mathrm{~g}^{-1}$ FW) (Drogoudi et al., 2008).

Table 2. Effect of stage of maturity and variety on selected elemental composition in apricot fruit (mean values $\pm \mathrm{SD}$ ).

\begin{tabular}{|c|c|c|c|c|}
\hline Variety and ripening stage & $\mathrm{K}$ & $\mathrm{Mg}$ & $\mathrm{Ca}$ & $\mathrm{Fe}$ \\
\hline & \multicolumn{4}{|c|}{$\mathrm{mg} 100 \mathrm{~g}^{-1} \mathrm{FW}$} \\
\hline Sirena I & $64.95 \pm 0.78 b$ & $40.05 \pm 2.34 \mathrm{c}$ & $164.87 \pm 3.86 a$ & $26.07 \pm 0.74 d$ \\
\hline Sirena II & $24.71 \pm 0.57 \mathrm{~m}$ & $7.44 \pm 0.44 \mathrm{~m}$ & $24.96 \pm 0.66 \mathrm{~m}$ & $8.87 \pm 0.11 \mathrm{~h}$ \\
\hline Sirena III & $53.97 \pm 0.88 d$ & $14.78 \pm 0.54 \mathrm{i}$ & $95.72 \pm 0.57 f$ & $9.31 \pm 0.10 \mathrm{~h}$ \\
\hline Silvana I & $53.67 \pm 0.43 d$ & $25.75 \pm 0.44 \mathrm{e}$ & $85.07 \pm 0.22 \mathrm{~g}$ & $42.27 \pm 1.05 b$ \\
\hline Silvana II & $18.35 \pm 0.510$ & $11.05 \pm 0.64 \mathrm{k}$ & $47.76 \pm 2.37 \mathrm{j}$ & $10.36 \pm 0.73 \mathrm{gh}$ \\
\hline Silvana III & $38.07 \pm 0.41 \mathrm{~h}$ & $14.30 \pm 0.20 \mathrm{ij}$ & $77.49 \pm 1.23 \mathrm{~h}$ & $15.93 \pm 6.21 \mathrm{f}$ \\
\hline Hungarian Best I & $65.28 \pm 0.38 b$ & $26.29 \pm 0.17 \mathrm{e}$ & $159.03 \pm 0.43 b$ & $24.90 \pm 0.69 d$ \\
\hline Hungarian Best II & $32.20 \pm 0.39 \mathrm{j}$ & $13.59 \pm 0.35 \mathrm{j}$ & $29.77 \pm 0.391$ & $10.97 \pm 0.47 \mathrm{gh}$ \\
\hline Hungarian Best III & $44.01 \pm 0.47 \mathrm{e}$ & $6.55 \pm 0.23 \mathrm{~m}$ & $43.71 \pm 0.64 \mathrm{k}$ & $8.79 \pm 0.54 \mathrm{gh}$ \\
\hline Olimp I & $40.40 \pm 0.74 \mathrm{~g}$ & $23.13 \pm 0.56 f$ & $111.77 \pm 0.61 d$ & $37.05 \pm 0.13 c$ \\
\hline Olimp II & $20.35 \pm 0.31 n$ & $17.19 \pm 0.15 h$ & $44.20 \pm 1.25 \mathrm{~g}$ & $10.42 \pm 0.24 \mathrm{gh}$ \\
\hline Olimp III & $36.13 \pm 0.29 \mathrm{i}$ & $19.59 \pm 0.34 \mathrm{~g}$ & $85.84 \pm 0.62 \mathrm{k}$ & $14.50 \pm 0.35 \mathrm{fg}$ \\
\hline Sulmona I & $42.99 \pm 0.90 f$ & $67.82 \pm 0.54 \mathrm{~A}$ & $121.70 \pm 0.67 \mathrm{c}$ & $27.34 \pm 0.36 \mathrm{~d}$ \\
\hline Sulmona II & $20.99 \pm 0.77 n$ & $16.14 \pm 0.35 \mathrm{hi}$ & $42.35 \pm 0.23 \mathrm{k}$ & $11.53 \pm 0.50 \mathrm{gh}$ \\
\hline Sulmona III & $29.57 \pm 0.44 \mathrm{k}$ & $15.19 \pm 0.78 \mathrm{i}$ & $97.88 \pm 0.59 \mathrm{ef}$ & $15.57 \pm 0.33 \mathrm{f}$ \\
\hline Selena I & $82.72 \pm 0.68 \mathrm{a}$ & $52.12 \pm 0.32 b$ & $42.93 \pm 0.83 \mathrm{k}$ & $64.00 \pm 1.53 \mathrm{a}$ \\
\hline Selena II & $28.23 \pm 0.721$ & $8.84 \pm 0.171$ & $73.29 \pm 0.91 \mathrm{i}$ & $12.26 \pm 1.00 \mathrm{~g}$ \\
\hline Selena III & $61.59 \pm 0.43 \mathrm{i}$ & $8.66 \pm 0.221$ & $41.07 \pm 0.18 \mathrm{k}$ & $13.47 \pm 0.95 \mathrm{fg}$ \\
\hline Sulina I & $36.13 \pm 0.53 \mathrm{k}$ & $31.22 \pm 0.79 d$ & $120.40 \pm 1.64 c$ & $22.36 \pm 0.89 \mathrm{e}$ \\
\hline Sulina II & $21.25 \pm 0.61 n$ & $18.67 \pm 0.23 g$ & $95.86 \pm 1.09 \mathrm{f}$ & $10.70 \pm 0.55 \mathrm{gh}$ \\
\hline Sulina III & $32.43 \pm 0.40 \mathrm{j}$ & $13.54 \pm 0.29 \mathrm{j}$ & $98.85 \pm 0.36 \mathrm{e}$ & $12.36 \pm 0.55 \mathrm{~g}$ \\
\hline
\end{tabular}

Different letters in the same column indicate significant differences according to Duncan's test $(\mathrm{P} \leq 0.05)$. 
The decrease in macro-element content in the HR stage followed by an increase in the RP stage can be explained by high demands and consumption of macronutrients in fruit development stages. At full maturity, when physiological processes have ended, there is a tendency for macro- and microelements to accumulate in the fruit (Iordanescu et al., 2012).

The level of minerals in apricot fruit from different cultivars might be genetically influenced and also influenced by environmentally determined conditions. The minerals in plants reflect the soil composition in which the plant is growing (Soetan et al., 2010). The lower K content in apricot fruit under our experimental conditions can be explained by the reduced supply of soil $\mathrm{K}$ and the absence of fertilization. Nonsignificant differences were pointed out for $\mathrm{K}$ content in the HR stage between 'Sulina', 'Sulmona', and 'Olimp'.

For all determined mineral compounds at different ripening stages of apricot fruit, Ca content was the highest. The $\mathrm{Ca}$ content in the ripening stage of apricot was similar to the results reported in other studies (Drogoudi et al., 2008; Hussain

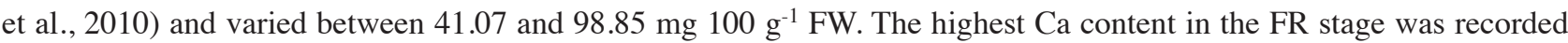
in 'Sulina' and 'Sirena' in the the UR stage. In this ripening stage, nonsignificant differences between 'Best Hungarian', 'Olimp', and 'Selena' were recorded ( $\mathrm{p}>0.05)$.

Iron micronutrient deficiencies are highly significant for public health (Soetan et al., 2010). The absence of Fe, which is is the main microelement, leads to the development of anemia. Known as a constituent of hemoglobin, Fe participates in the active transport of gas to the acid-base balance adjustment; it is found in the composition of reducing oxidation enzymes (cytochromes, catalase, and peroxidase) participating in the tissue respiration processes. The daily recommended intake for adults is $15 \mathrm{mg}$ (Johnson-Wimbley, 2011).

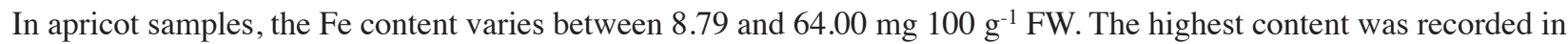
'Selena' at the UR stage and the lowest value in 'Best Hungarian' at the FR stage. Generally, the Fe content decreased in the following order: UR > FR > HR. Hussain et al. (2010) reported that the Fe level in apricots varies between 1.4 and 2.4 $\mathrm{mg} 100 \mathrm{~g}^{-1}$ depending on the variety.

All selected elements maintained a similar profile during the ripening process and there were nonsignificant changes in Fe content at the FR stage between 'Sulina' III, 'Selena' III, 'Olimp' III, and 'Best Hungarian' III, and at the HR stage between 'Sulina' II, 'Selena' II, 'Sulmona' II, ‘Olimp’ II, ‘Best Hungarian' II, and ‘Silvana' II (p >0.05).

In conclusion, apricot fruit provide important macro-elements and $\mathrm{Fe}$, which are necessary for the body to develop well. The study of the accumulation of elementary nutrients during fruit ripening represents a useful tool for fruit growers to manage production quality.

\section{Antioxidant parameters}

Total phenolic content, AC expressed as FRAP, and vitamin C content are revealed in Table 3.

Experimental results showed that the dynamics of TP and AC for different apricot varieties cultivated in Romania were directly correlated with the ripening stage and displayed significant increases in TP during the ripening of apricot fruit. Similar results were obtained by Hegedüs et al. (2011). On the contrary, Dragovic-Uzelac et al. (2009) and Cosmulescu et al. (2018) highlight that immature fruit showed the highest polyphenol level, which decreased for semi-mature fruit, and did not change remarkably for ripe fruit. The inconsistencies might be explained by genotypic differences or discrepancies between the assays that were conducted (Hegedüs et al., 2011).

Our results showed that TP content in different apricot cultivars varied between 0.45 and $1.10 \mathrm{mg} \mathrm{GA} \mathrm{g}^{-1} \mathrm{FW}$ : this is in the same value range that Caliskan et al. (2012) reported for some Turkish apricot varieties. Akin et al. (2008) reported higher phenolic compound content (42.33-81.80 $\left.\mathrm{mg} \mathrm{GA} \mathrm{g}^{-1} \mathrm{DW}\right)$ in apricot fruit. The highest values were recorded for 'Best Hungarian' at all ripening stages, while the lowest values were obtained for 'Sulmona'. At the FR stage, the highest TP values were obtained for 'Silvana', 'Olimp', and 'Selena' (0.93-1.10 $\left.\mathrm{mg} \mathrm{GA} \mathrm{g}^{-1} \mathrm{FW}\right)$. The results are in accordance with other studies and show the impact of the variety on the bioactive compound content of apricot fruit (Drogoudi et al., 2008; Dragovic-Uzelac et al., 2009; Hegedüs et al., 2011). The TP content of apricot cultivars increased throughout the ripening period, and the most notable difference was recorded in 'Silvana' ( $\left.0.62 \mathrm{mg} \mathrm{GA} \mathrm{g}^{-1} \mathrm{FW}\right)$ between the UR and FR stages. The TP content showed nonsignificant differences $(\mathrm{p}>0.05)$ between ripening stages; this suggests a similar profile of antioxidant principles in different development stages of apricot fruit.

The results for antioxidant activity using the FRAP assay (Table 3) displayed an increase of this parameter during the ripening of 'Best Hungarian', 'Olimp', 'Sulmona', and 'Selena' apricots. On the contrary, 'Sirena', 'Silvana', and 'Sulina' 
Table 3. Effect of stage of maturity and variety on antioxidant parameters in apricot fruit (mean values $\pm \mathrm{SD}$ ).

\begin{tabular}{lllc}
\hline $\begin{array}{l}\text { Variety and } \\
\text { ripening stage }\end{array}$ & $\begin{array}{c}\text { Antioxidant } \\
\text { capacity }\end{array}$ & $\begin{array}{c}\text { Phenolic } \\
\text { content }\end{array}$ & $\begin{array}{c}\text { Vitamin } \\
\mathrm{C}\end{array}$ \\
\hline Sirena I & $\begin{array}{l}\mu \mathrm{Fe}^{2+} \mathrm{g}^{-1} \mathrm{FW} \\
\mathrm{mg} \mathrm{GA} \mathrm{g}^{-1} \mathrm{FW}\end{array}$ & $\mathrm{mg} \mathrm{g}^{-1} \mathrm{FW}$ \\
Sirena II & $0.045 \pm 0.006 \mathrm{f}$ & $0.61 \pm 0.02 \mathrm{de}$ & $0.454 \pm 0.012 \mathrm{fg}$ \\
Sirena III & $0.217 \pm 0.014 \mathrm{c}$ & $0.80 \pm 0.02 \mathrm{c}$ & $0.544 \pm 0.010 \mathrm{e}$ \\
Silvana I & $0.078 \pm 0.005 \mathrm{f}$ & $0.48 \pm 0.05 \mathrm{e}$ & $0.239 \pm 0.006 \mathrm{k}$ \\
Silvana II & $0.130 \pm 0.009 \mathrm{de}$ & $0.75 \pm 0.03 \mathrm{~cd}$ & $0.346 \pm 0.023 \mathrm{i}$ \\
Silvana III & $0.122 \pm 0.002 \mathrm{e}$ & $1.10 \pm 0.09 \mathrm{a}$ & $0.542 \pm 0.011 \mathrm{e}$ \\
Hungarian Best I & $0.060 \pm 0.009 \mathrm{f}$ & $0.71 \pm 0.02 \mathrm{~cd}$ & $0.233 \pm 0.028 \mathrm{k}$ \\
Hungarian Best II & $0.187 \pm 0.006 \mathrm{~cd}$ & $0.74 \pm 0.03 \mathrm{~cd}$ & $0.457 \pm 0.061 \mathrm{fg}$ \\
Hungarian Best III & $0.230 \pm 0.036 \mathrm{c}$ & $0.83 \pm 0.05 \mathrm{bc}$ & $0.498 \pm 0.027 \mathrm{f}$ \\
Olimp I & $0.066 \pm 0.029 \mathrm{f}$ & $0.56 \pm 0.02 \mathrm{de}$ & $0.273 \pm 0.017 \mathrm{jg}$ \\
Olimp II & $0.159 \pm 0.003 \mathrm{de}$ & $0.63 \pm 0.09 \mathrm{de}$ & $0.363 \pm 0.01 \mathrm{hi}$ \\
Olimp III & $0.276 \pm 0.005 \mathrm{~b}$ & $1.04 \pm 0.07 \mathrm{ab}$ & $0.867 \pm 0.041 \mathrm{~b}$ \\
Sulmona I & $0.068 \pm 0.024 \mathrm{f}$ & $0.45 \pm 0.01 \mathrm{e}$ & $0.323 \pm 0.142 \mathrm{~h}$ \\
Sulmona II & $0.074 \pm 0.057 \mathrm{~d}$ & $0.51 \pm 0.13 \mathrm{e}$ & $0.544 \pm 0.022 \mathrm{e}$ \\
Sulmona III & $0.167 \pm 0.025 \mathrm{f}$ & $0.62 \pm 0.14 \mathrm{de}$ & $0.926 \pm 0.049 \mathrm{a}$ \\
Selena I & $0.079 \pm 0.011 \mathrm{dc}$ & $0.56 \pm 0.02 \mathrm{de}$ & $0.442 \pm 0.031 \mathrm{~g}$ \\
Selena II & $0.199 \pm 0.011 \mathrm{a}$ & $0.59 \pm 0.06 \mathrm{de}$ & $0.606 \pm 0.016 \mathrm{~d}$ \\
Selena III & $0.333 \pm 0.068 \mathrm{de}$ & $0.93 \pm 0.01 \mathrm{~b}$ & $0.814 \pm 0.0118 \mathrm{c}$ \\
Sulina I & $0.055 \pm 0.006 \mathrm{f}$ & $0.44 \pm 0.11 \mathrm{e}$ & $0.363 \pm 0.008 \mathrm{hi}$ \\
Sulina II & $0.131 \pm 0.009 \mathrm{e}$ & $0.50 \pm 0.02 \mathrm{e}$ & $0.296 \pm 0.008 \mathrm{j}$ \\
Sulina III & $0.074 \pm 0.015 \mathrm{f}$ & $0.66 \pm 0.01 \mathrm{~d}$ & $0.609 \pm 0.010 \mathrm{~d}$ \\
\hline Different & & $0.72 \pm 0.01 \mathrm{~d}$ & $0.430 \pm 0.026 \mathrm{f}$ \\
\hline
\end{tabular}

Different letters in the same column indicate significant differences according to Duncan's test $(\mathrm{P} \leq 0.05)$.

GA: Gallic acid; FW: fresh weight.

recorded the highest antioxidant activity at the HR stage. The highest FRAP activity value, $0.357 \mu \mathrm{M} \mathrm{Fe} \mathrm{g}^{2+} \mathrm{gW}^{-1}$, was obtained in 'Sirena' at the HR stage, while the lowest value was detected in the same cultivar at the UR stage $(0.045 \mu \mathrm{M}$ $\left.\mathrm{Fe}^{2+} \mathrm{g}^{-1}\right)$. The AC values, expressed as FRAP, recorded nonsignificant differences at the UR stage among all varieties, except 'Selena' $(\mathrm{p}>0.05)$.

Apricot vitamin C content gradually increased throughout the ripening stages (Table 3), except 'Serena' and 'Sulina' in which the highest vitamin $C$ content was found at the HR phase. There was a nonsignificant difference $(p>0.05)$ between the following varieties and ripening stages: a) 'Sirena' I, 'Sirena' II, 'Best Hungarian' II, 'Olimp' I, and 'Selena' I; b) 'Sirena' I, 'Best Hungarian' II, and 'Best Hungarian' III; c) 'Sirena' II, 'Olimp' II, 'Sulmona' I, and 'Sulina' I; d) 'Silvana' II, 'Olimp' I, and ‘Sulina' I; e) 'Sulmona' II, 'Silvana' III, and 'Sirena' III; f) 'Sulina' III and 'Selena' II. Although ripe 'Olimp' and 'Sulmona' fruit contained double the quantities of vitamin C found in 'Best Hungarian' and 'Silvana', vitamin $\mathrm{C}$ contents in unripe fruit of the cultivars were identical. The proportions of accumulated quantities of vitamin $\mathrm{C}$ were very similar in all varieties, and the highest accumulated amount occurred in the second half of the ripening process during the HR and FR stages. A similar effect during the ripening of apricot fruit was reported by Hegedüs et al. (2011) in Magyar varieties, suggesting that the dynamics in the accumulation of vitamin $\mathrm{C}$ in apricot fruit is less influenced by environmental conditions or genotype and more by the physiological consequences of ripening (Hegedüs et al., 2011).

\section{Correlations between variables}

The analysis of correlation (Table 4) highlights a strong ( $\mathrm{r}>0.7)$ positive correlation between $\mathrm{Mg} / \mathrm{Fe}(\mathrm{r}=0.878)$, a strong negative correlation between Moisture/Ash $(r=-0.718)$, a moderate $(r>0.5)$ positive correlation between the pairs Fe/Moisture $(r=0.562)$, Protein/Mg $(r=0.609)$, Protein/Fe $(r=0.594), T P / P(r=0.643), T C / T P(r=0.520)$, $\mathrm{Mg} / \mathrm{K}(\mathrm{r}=0.687), \mathrm{Fe} / \mathrm{K}(0.693)$, and $\mathrm{AC} / \mathrm{TP}(\mathrm{r}=0.526)$, as well as a moderate negative correlation for the pairs TP/Moisture $(r=-0.603)$, Protein/TC $(r=-0.548)$, Protein/Vitamin C $(r=-0.517)$, Protein/TP $(r=-0.643)$, Moisture/ $\mathrm{TC}(\mathrm{r}=-0.636), \mathrm{AC} / \mathrm{Mg}(\mathrm{r}=-0.512)$, and $\mathrm{AC} / \mathrm{Ca}(\mathrm{r}=-0.535)$. We determined mutual correlations between individual elements and antioxidant parameters, which can prove dependence between chemical compounds. The highest correlation coefficient values were determined for the elemental pairs $\mathrm{Fe} / \mathrm{K}$ and $\mathrm{Mg} / \mathrm{K}$ and antioxidant parameters TP/P and TC/TP. In these cases, we can presume their mutual connection in apricot fruit. 
Table 4. Matrix of Pearson linear correlations.

\begin{tabular}{lccccccccccccrr}
\hline & Mean & SD & Moisture & Ash & Protein & Fat & TC & K & Mg & Ca & Fe & AC & TP & Vit C \\
\hline Moisture & 84.45 & 2.38 & 1.00 & $\mathbf{- 0 . 7 1 8}$ & 0.486 & 0.083 & $\mathbf{- 0 . 6 3 6}$ & 0.169 & 0.468 & 0.027 & $\mathbf{0 . 5 6 2}$ & -0.258 & $\mathbf{- 0 . 6 0 3}$ & -0.182 \\
Ash & 3.65 & 1.78 & $\mathbf{- 0 . 7 1 8}$ & 1.00 & -0.258 & 0.132 & -0.057 & -0.155 & -0.254 & 0.186 & -0.442 & 0.065 & 0.342 & 0.176 \\
Protein & 0.93 & 0.20 & 0.486 & -0.258 & 1.00 & -0.042 & $\mathbf{- 0 . 5 4 8}$ & 0.382 & $\mathbf{0 . 6 0 9}$ & 0.395 & $\mathbf{0 . 5 9 4}$ & -0.349 & $\mathbf{- 0 . 6 4 3}$ & $\mathbf{- 0 . 5 1 7}$ \\
Fat & 0.29 & 0.13 & 0.083 & 0.132 & -0.042 & 1.00 & -0.303 & -0.377 & -0.241 & 0.109 & -0.403 & 0.111 & -0.017 & 0.187 \\
TC & 10.65 & 1.92 & $\mathbf{- 0 . 6 3 6}$ & -0.057 & $\mathbf{- 0 . 5 4 8}$ & -0.303 & 1.00 & -0.148 & -0.457 & -0.330 & -0.353 & 0.314 & $\mathbf{0 . 5 2 0}$ & 0.099 \\
K & 40.46 & 18.45 & 0.169 & -0.155 & 0.382 & -0.377 & -0.148 & 1.00 & $\mathbf{0 . 6 8 7}$ & 0.348 & $\mathbf{0 . 6 9 3}$ & -0.187 & 0.054 & -0.063 \\
$\mathrm{Mg}$ & 19.62 & 15.01 & $\mathbf{0 . 4 6 8}$ & -0.254 & $\mathbf{0 . 6 0 9}$ & -0.241 & -0.457 & $\mathbf{0 . 6 8 7}$ & 1.00 & 0.241 & $\mathbf{0 . 8 7 8}$ & $\mathbf{- 0 . 5 1 2}$ & -0.334 & -0.237 \\
$\mathrm{Ca}$ & 76.96 & 40.18 & 0.027 & 0.186 & 0.395 & 0.109 & -0.330 & 0.348 & 0.241 & 1.00 & 0.196 & $\mathbf{- 0 . 5 3 5}$ & -0.140 & -0.143 \\
$\mathrm{Fe}$ & 18.91 & 14.48 & $\mathbf{0 . 5 6 2}$ & -0.442 & $\mathbf{0 . 5 9 4}$ & -0.403 & -0.353 & $\mathbf{0 . 6 9 3}$ & $\mathbf{0 . 8 7 8}$ & 0.196 & 1.00 & -0.497 & -0.367 & -0.315 \\
$\mathrm{AC}$ & 0.15 & 0.093 & -0.258 & 0.065 & -0.349 & 0.111 & 0.314 & -0.187 & $\mathbf{- 0 . 5 1 2}$ & $\mathbf{- 0 . 5 3 5}$ & -0.497 & 1.00 & $\mathbf{0 . 5 2 6}$ & 0.494 \\
$\mathrm{TP}$ & 0.70 & 0.175 & $\mathbf{- 0 . 6 0 3}$ & 0.342 & $\mathbf{- 0 . 6 4 3}$ & -0.017 & $\mathbf{0 . 5 2 0}$ & 0.054 & -0.334 & -0.140 & -0.367 & $\mathbf{0 . 5 2 6}$ & 1.00 & 0.467 \\
Vit C & 0.499 & 0.201 & -0.182 & 0.176 & $\mathbf{- 0 . 5 1 7}$ & 0.187 & 0.099 & -0.060 & -0.237 & -0.143 & -0.315 & 0.494 & 0.467 & 1.00 \\
\hline
\end{tabular}

SD: Standard deviation; TC: total carbohydrates; AC: antioxidant capacity; TP: total phenolic content; Vit C: vitamin C.

In addition, the multi-parametric statistical evaluation method using PCA (Figures 1 and 2) and CA (Figure 3) were used for further data analysis.

Based on a linear correlation matrix, PCA was applied to the mean values of the measured traits to study which parameters contributed the most to total data variation. The PCA produced 12 components. The first two principal components accounted for $40.20 \%$ and $15.63 \%$ (a total of 55.83\%) of the variance, respectively. The most important variables integrated in the first component were moisture, protein, $\mathrm{Mg}$, and $\mathrm{Fe}$, which were positively correlated with this component; on the other hand, ash, TC, FRAP, TP, and Vit C were negatively correlated with this first component. The second component was positively correlated with fat and negatively correlated with $\mathrm{K}$.

The similarity among cultivars was examined when each sample was plotted using the first and second principal components, which retained $55.83 \%$ of the total variance (Figure 2), and showed a clustering tendency. This led us to perform CA and represent the case by a simplified dendrogram plot. We can clearly identify apricot cultivars with distant values by this data presentation. Using CA, we were able to suggest a dendrogram that divides individual apricot cultivars into two representative clusters based on the mutual similarity of their measured parameters. Clusters classify individual apricot cultivars into six groups based on similar characteristics: Group 1: 'Sirena' I and 'Hungarian Best' I; Group 2:

Figure 1. Projection of the variables on the plane spanned by the first and second principal components.

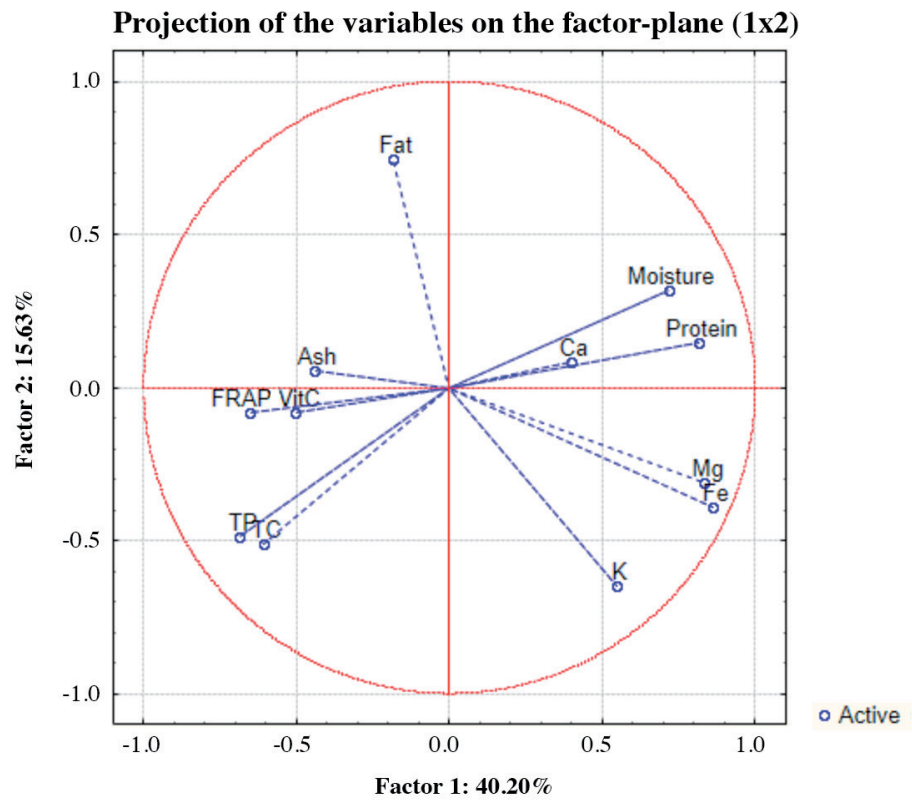

TC: Total carbohydrates; TP: total phenolic content; FRAP: ferric reducing antioxidant power. 
Figure 2. Projection of the cases on the plane spanned by the first and second principal components.

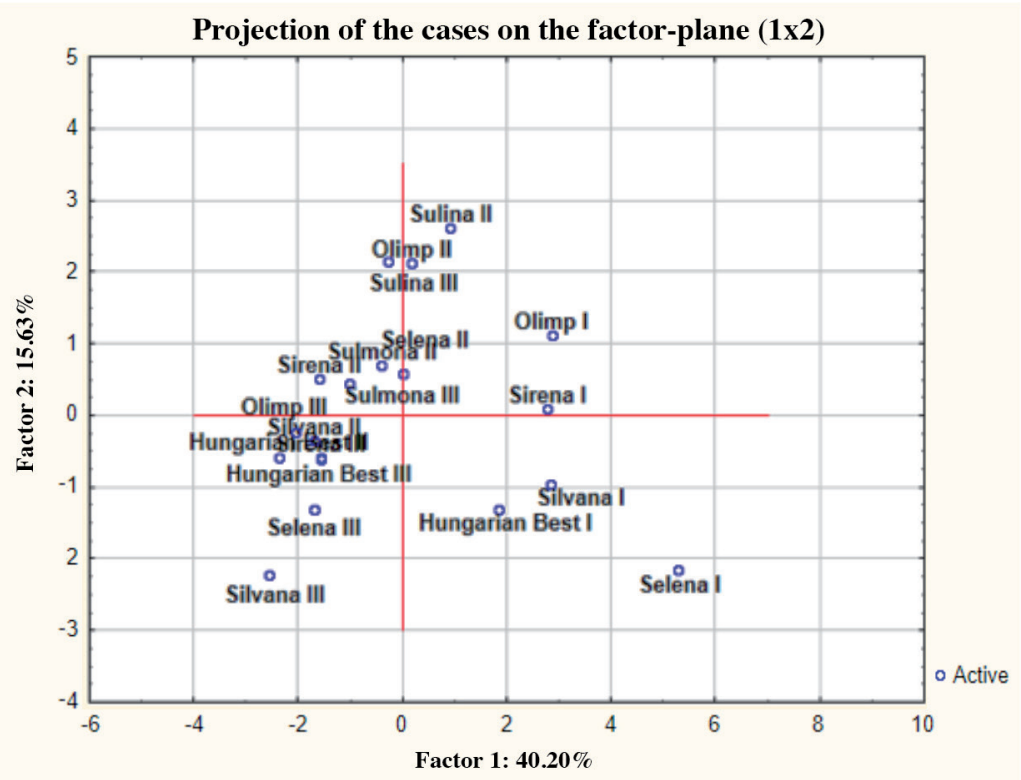

Figure 3. Cluster dendrogram of apricot varieties.

Tree diagram for 19 cases ward's method Euclidean distances

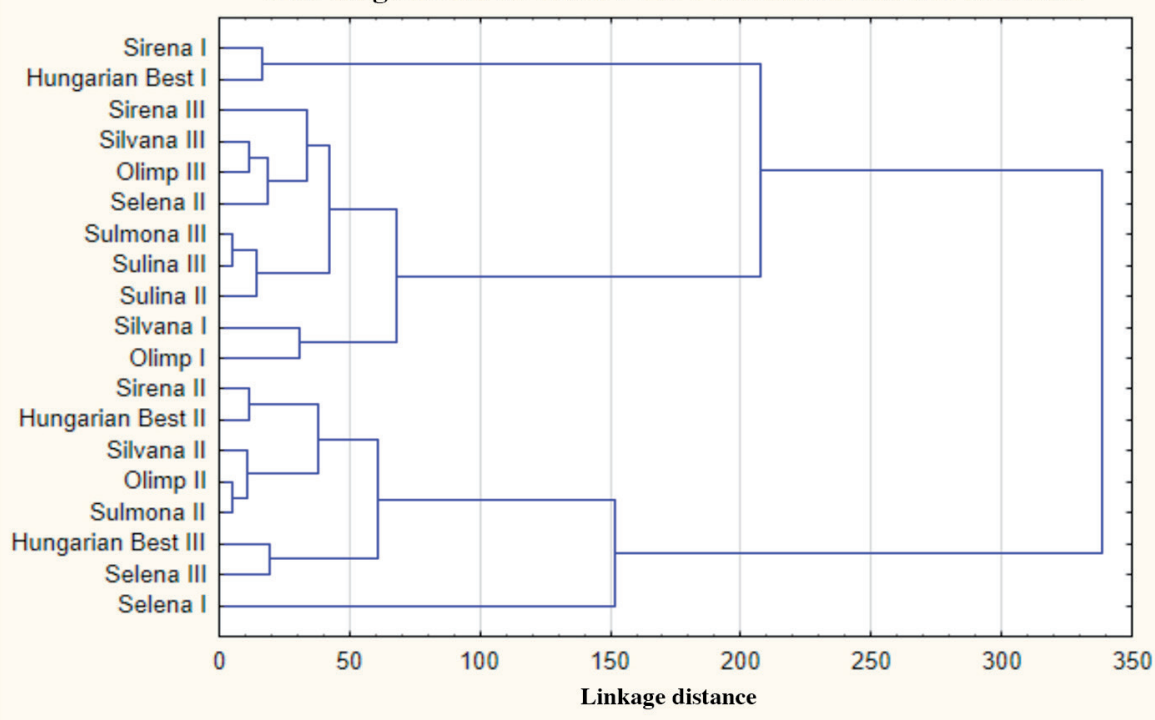

'Sirena' III, ‘Silvana' III, 'Olimp’ III, ‘Selena’ II, 'Sulmona’ III, ‘Sulina’ III, and ‘Sulina’ II; Group 3: 'Silvana’ I and 'Olimp' I; Group 4: 'Sirena' II, 'Hungarian Best' II, 'Silvana' II, 'Olimp' II, and 'Sulmona' II; Group 5: 'Hungarian Best' III and 'Selena' III; and Group 6: 'Selena' I. It is noted that group similarity is based on the plant stage.

\section{CONCLUSIONS}

This study highlights the importance of ripening stages on the accumulation of nutrients and antioxidant principles in apricot fruit. In this regard, the study is intended to be a useful tool in pomiculture for the optimal management of the nutritional potential of apricot fruit. The results indicated that the highest content of macro-elements was detected in 
the first ripening stage, while the highest accumulated amount of vitamin $\mathrm{C}$ occurred in the second half of the ripening process. The dynamics of total phenolic content displays a significant increase during ripening, and the highest value of antioxidant activity was obtained in 'Sirena' at the half-ripe stage.

Mutual correlations were determined between individual elements and antioxidant parameters, which can prove dependence between chemical compounds. The highest correlation coefficient values were determined for the elemental pairs $\mathrm{Fe} / \mathrm{K}$ and $\mathrm{Mg} / \mathrm{K}$, nutritional/antioxidant parameters, protein/total polyphenols, and carbohydrates/total polyphenols.

The multi-parametric statistical evaluation method using principal component analysis (PCA) and cluster analysis (CA) divided individual apricot cultivars into two representative clusters and six groups based on similar characteristics.

\section{ACKNOWLEDGEMENTS}

This research study was supported by a Romanian grant Priority Axis 2-Environmental protection and risk management, 2.1 -Environmental protection and sustainable use of natural resources, entitled: "Joint project for conservation and sustainable use of plant genetic resources from border areas as consequences of climate change", acronym GERMOSAVE.

The chemical and microbiological experimental research was performed in the Interdisciplinary Research Platform (PCI) belonging to the Banat University of Agricultural Sciences and Veterinary Medicine King Michael I of Romania in Timisoara, Romania.

\section{REFERENCES}

Akin, E.B., Karabulut, I., and Topcu, A. 2008. Some compositional properties of main Malatya apricot (Prunus armeniaca L.) varieties. Food Chemistry 107:939-948.

AOAC. 1997. Official methods of analysis. Association of Official Analytical Chemists (AOAC), Arlington, Virginia, USA. Secs. 920 954.01; 920.39; 923.03 and 925.09.

Ayour, J., Sagar, M., Harrak, H., Alahyane, A., and Benichou, M. 2017. Evolution of some fruit quality criteria during ripening of twelve new Moroccan apricot clones (Prunus armeniaca L.) Scientia Horticulturae 215:72-79.

Caliskan, O., Bayazit, S., and Sumbul, A. 2012. Fruit quality and phytochemical attributes of some apricot (Prunus armeniaca L.) cultivars as affected by genotypes and seasons. Notulae Botanicae Horti Agrobotanici Cluj-Napoca 40(2):284-294.

Campbell, O.E., Merwin, I.A., and Padilla-Zakour, O.I. 2011. Nutritional quality of New York peaches and apricots. New York Fruit Quarterly 19(4):12-16.

Cosmulescu, S., Trandafir, I., Nour, V., Achim, G., Botu, M., and Iordanescu, O. 2018. Variation of bioactive compounds and antioxidant activity of Jujube (Ziziphus jujuba) fruits at different stages of ripenin. Notulae Botanicae Horti Agrobotanici Cluj-Napoca 46(1):134-137.

Dragovic-Uzelac, V., Kovacevic, D.B., Levaj, B., Pedisic, S., Mezak, M., and Tomljenovic, A. 2009. Polyphenols and antioxidant capacity in fruits and vegetables common in the Croatian diet. Agriculturae Conspectus Scientificus 74(3):175-179.

Drogoudi, P.D., Vemmos, S., Pantedelis, G., Petri, E., Tzoutzoukou, C., and Karayannis, I. 2008. Physical characters and antioxidant, sugar, and mineral nutrient contents in fruit from 29 apricot (Prunus armeniaca L.) cultivars and hybrids. Journal of Agricultural and Food Chemistry 56:10754-10760.

Fan, X., Xi, Y., Zhao, H. Liu, B., and Jiang, W. 2018. Improving fresh apricot (Prunus armeniaca L.) quality and antioxidant capacity by storage at near freezing temperature. Scientia Horticulturae 231(27):1-10.

Fratianni, F., Ombra, M.N., d'Acierno, A., Cipriano, L., and Nazzaro, F. 2018. Apricots: biochemistry and functional properties. Current Opinion in Food Science 19:23-29.

Gatti, E., Defilippi, B.G., Predieri, S., and Infante R. 2009. Apricot (Prunus armeniaca L.) quality and breeding perspectives. Journal of Food, Agriculture \& Environment 7(3\&4):573-580.

Hegedüs, A., Pfeiffer, P., Papp, N., Abrankó, L., Blázovics, A., Pedryc, A., et al. 2011. Accumulation of antioxidants in apricot fruit through ripening: characterization of a genotype with enhanced functional properties. Biological Research 44:339-344.

Hussain, P.R., Chatterjee, S., Variyar, P.S., Sharma, A., Dar, M.A., and Wani, A.M. 2013. Bioactive compounds and antioxidant activity of gamma irradiated sun dried apricots (Prunus armeniaca L.) Journal of Food Composition and Analysis 30(2):59-66.

Hussain, A., Yasmin, A., and Javed, A. 2010. Comparative study of chemical composition of some dried apricot varieties grown in northern areas of Pakistan. Pakistan Journal of Botany 42(4):2497-2502.

Iordanescu, O.A., Alexa, E., Micu, R., and Poiana, M.A. 2012. Bioactive compounds and antioxidant properties of apples cultivars from Romania in different maturity stage. Journal of Food Agriculture and Environment 10(1):147-151. 
Iordanescu, O.A., and Micu, R.E. 2012. Fruit culture and pomology. Eurobit Publishing, Timisoara, Romania.

Johnson-Wimbley, T.D. 2011. Diagnosis and management of iron deficiency anemia in the $21^{\text {st }}$ century. Therapeutic Advances in Gastroenterology 4(3):177-184.

Leccese, A., Bureau, S., Reich, M., Renard, C., Audergon, J.C., Mennone, C., et al. 2010. Pomological and nutraceutical properties in apricot fruit: Cultivation systems and cold storage fruit management. Plant Foods Human Nutrition 65:112-120.

Milosevic, T., Milosevic, N., Glisic, I., and Krska, B. 2010. Characteristics of promising apricot (Prunus armeniaca L.) genetic resources in Central Serbia based on blossoming period and fruit quality. Horticultural Science (Prague) 37:46-55

Mratinic, E., Popovski, B., Milosevic, T., and Popovska, M. 2011. Evaluation of apricot fruit quality and correlations between physical and chemical attributes. Czech Journal of Food Science 29(2):161-170.

Negrea, M., Radulov, I., Ardelean, L., and Rusu L.C. 2012. Mineral nutrients compositions of Daucus carota culture in different stages of morphogenesis. Revista de Chimie (Bucharest) 63(9):887-892.

Pliszka, B., Wazbinska, J., and Ciolkowska, G.H. 2009. Polyphenolic compounds and bioelements in fruits of eastern teaberry (Gaultheria procumbens L.) harvested in different fruit maturity phases. Journal of Elementology 14(2):341-348.

Rop, O., Sochor, J., Jurikova, T., Zitka, O., Skutkova, H., Mlcek, J., et al. 2011. Effect of five different stages of ripening on chemical compounds in medlar (Mespilus germanica L.) Molecules 16:74-91.

Sochor, J., Skutkova, H., Babula, P., Zitka, O., Cernei, N., Rop, O., et al. 2011. Mathematical evaluation of the amino acid and polyphenol content and antioxidant activities of fruits from different apricot cultivars. Molecules 16:7428-7457.

Soetan, K.O., Olaiya, C.O., and Oyewole, O.E. 2010. The importance of mineral elements for humans, domestic animals and plants: A review. African Journal of Food Science 4(5):200-222.

Suarez, B., Alvarez, A.L., Dineiro Garcia, Y., Barrio, G., Lobo D., and Parra, A.P.F. 2010. Phenolic profiles, antioxidant activity and in vitro antiviral properties of apple pomace. Food Chemistry 120:339-342. 